\title{
Outcomes of the Clean Development Mechanism in Argentina
}

\section{Gabriel Blanco, Verónica Córdoba, Romina Baldi, Mónica Fernández, Estela Santalla*}

Centro de Tecnologías Ambientales y Energía, Facultad de Ingeniería, UNCPBA, Olavarría, Argentina

Email: *esantall@fio.unicen.edu.ar

How to cite this paper: Blanco, G., Córdoba, V., Baldi, R., Fernández, M. and Santalla, E. (2016) Outcomes of the Clean Development Mechanism in Argentina. American Journal of Climate Change, 5, 431-447. http://dx.doi.org/10.4236/ajcc.2016.54032

Received: October 17, 2015

Accepted: February 18, 2016

Published: November 2, 2016

Copyright $\odot 2016$ by authors and Scientific Research Publishing Inc. This work is licensed under the Creative Commons Attribution International License (CC BY 4.0).

http://creativecommons.org/licenses/by/4.0/ cc) (i) Open Access

\begin{abstract}
This paper summarizes the results of the implementation of the CDM in Argentina during the first period of commitment of the Kyoto Protocol. From a total of sixtyfive projects ideas, forty-four achieved registration under the CDM EB while the rest remained approved at national level (12), under evaluation (2), suspended (5) or rejected (2). Most of the projects focused on the generation of electricity from renewable energy, mainly wind energy and the use of landfill gas and methane for energy. Emissions reductions achieved 33.4\% of the expected CERs up to 2012 with strong differences among sectors. Results demonstrated that under the current Argentina's energy policy framework, the income by the selling of CERs covered less than $6 \%$ of the incremental costs for renewable energy projects. A sensitivity analysis to evaluate the impact of CDM in the coverage of incremental costs for renewable energy based on the prices of both the energy in the local market and the CER demonstrated that the best conditions would only cover $15 \%$ of those costs. The contribution of CDM to technology transfer in Argentina was minor considering that $45 \%$ of the projects qualified as type III where technological learning and capacity building were limited at the level of operation and maintenance of a foreign technology. Domestic and external barriers that prevented a better performance of CDM projects in terms of GHG mitigation, technology transfer and the contribution to a sustainable development were also analyzed.
\end{abstract}

\section{Keywords}

Clean Development Mechanism, GHG Emissions, Incremental Cost, Renewable Energy, Argentina

\section{Introduction}

The Clean Development Mechanism (CDM) was designed with the two objectives to 
contribute to local sustainable development in the host country and to assist Annex-I countries to achieve their emission reduction targets in a cost-efficient manner. Many authors have pointed out that the CDM was created under a market design and its contribution to sustainable development was not actually incorporated in this design [1] [2]. The absence of international standards for sustainable development alongside a highly competitive supply side of the CDM worked in favor of the cost-efficient emission reduction objective.

Some authors indicated that the contribution to sustainable development is not well reflected in Certified Emission Reductions (CERs) prices pointing out that while a large part $(72 \%)$ of the expected CERs during the first commitment period are likely to represent real and measurable emission reductions, less than $1 \%$ are likely to contribute significantly to sustainable development in the host country [1]. Particularly in the energy efficiency sector with emphasis in India's situation it has been highlighted that sustainable development and additionality are often assessed in a cursory manner and besides resource conservation, energy efficiency projects do not create much qualitative sustainable development benefits and technology transfer occurred rarely [3].

It has been observed that CDM is failing in the promotion of sustainable development, most notably by not financing projects that help in the long-term transition of developing country energy sectors towards renewable energy technologies [4]. Industrialized countries' governments and corporations are using the CDM to reduce the costs of complying with their Kyoto targets, searching for least-cost carbon credits. Therefore, projects that capture or destroy gases with high global warming potentials like methane, nitrous oxide and hydro-fluorocarbons become the most common CDM projects. While renewable energy projects are the most numerous ones, accounting for $41 \%$ of all projects, comparing credit volumes is a better way to judge how successfully the CDM has promoted renewable energies. The reason for the CDM as a market mechanism, is not promoting renewable energy projects as these require more investment to produce a carbon credit than most other available options, increasing investment risks and diminishing profits [4].

It has been pointed out that funds allocated for the mitigation activities under CDM belong mainly to public sector and they are small relative to other flows of foreign investment from developed to developing countries [2]. While other authors indicated that the quality of domestic institutions, internal political stability and efforts to market $\mathrm{CDM}$ projects to investors is important for individual countries to secure their share in the CDM market [5]. In the same line [6] agreed that the development of CDM projects is stimulated by favorable economic, social and technical environments in host countries as well as supportive CDM administration. The same author highlighted that for many of the most poorly performing projects, failure is attributable to technical and operational problems at the initial stage of project implementation, which highlights the importance of well-prepared PDDs. It has been reported a strong correlation between a country's CDM performance and its economic conditions which support the market-oriented CDM framework that favors countries with the better economics and 
investment conditions of which foreign direct investment (FDI) is a very influential factor [7].

Technology transfer claims for CDM projects have been analyzed by several authors. The analysis of this issue from a high number of projects (3296 by 2008) founded that $36 \%$ of that registered projects (that represented about $59 \%$ of the annual emission reductions) claim some technology transfer. About half of them claim transfer of both equipment and knowledge from which 70\% was originated from Japan, Germany, USA, France, and Great Britain, being Japan who has the closest relationship between credit purchases and technology supply [8].

As one of the main goals, CDM was expected to stimulate transfer of climate-friendly technologies [9]. A total of 644 CDM projects were registered up to May 2007, but just in the $50 \%$ of these projects international technology transfer took place and included not only transfer of equipment but also transfer of knowledge and operation skills. The main areas in which technology transfer takes place are end-of-pipe destruction of non$\mathrm{CO}_{2}$ GHG with high global warming potentials, such as $\mathrm{HFCs}, \mathrm{CH}_{4}$ and $\mathrm{N}_{2} \mathrm{O}$. In addition, an econometric analysis of the drivers shows that technology transfer in large projects is more likely. Furthermore, the probability of transfer is $50 \%$ higher when the project is developed by a subsidiary of an Annex 1 company, however the presence of an official credit buyer has a lower impact that the previous one.

Finally, particular circumstances of developing countries such as regional characteristics, population concentration, scale of projects, cultural issues that may prevent technology transfer in an effective way could be alleviated by creating appropriate regulatory framework that provide incentives to private sectors to invest, develop and implement climate friendly projects [10]. In this context, the assessment of the current Argentina's policy scenario regarding renewable energy promotion will be analyzed in order to value the impact of CDM implementation during the first commitment period.

Until the end of 2012 a total of 44 projects have been registered by the Executive Board (EB) of the United Nations and yet no analysis had been carried out to assess the impact on GHG emission reductions, technology transfer issues, promotion of cleaner technologies, the contribution to sustainable development and the input of the CDM to cover the incremental costs of new technologies.

This paper describes and analysis the results of the implementation of the CDM projects in Argentina, their impact on the contribution to sustainable development, and the GHG emission reductions achieved. It also attempts to explain some barriers under Argentina's scenario that prevented the development of more GHG mitigation projects under this mechanism.

\section{Results and Discussion}

\subsection{Description of the Argentina's Legal Framework for CDM Project Activities}

Argentina ratified the UNFCCC and the Kyoto Protocol through the National Laws No 24.295 and 25.438 respectively and created the National Office for the Clean Develop- 
ment Mechanism through the Decree No 822 in 1988. Argentina has developed a CDM National Evaluation System through the Resolution 825/04 that establishes the procedure for presentation, evaluation, approval or rejection of CDM projects at the Designated National Authority (DNA). The DNA is the National Office of the Clean Development Mechanism (OAMDL) that is part of the former National Secretary of Environment and Sustainable Development (SAyDS), now a national ministry. Argentina also established the ACF (Argentinean Carbon Fund) to support developers and project owners to submit and register projects under the CDM. The ACF was also part of the SAyDS and in its best times it had more than one hundred and fifty project ideas in the pipeline.

\subsection{Description of the CDM Projects in Argentina}

Based on the information published in the official website of the CDM sixty five GHG mitigation projects were submitted until December 2012. Forty four of them achieved registration at the $\mathrm{CDM} \mathrm{EB}$, twelve were approved at national level and are now waiting for registration, five were suspended, two are still under assessment and two were rejected. From the registered projects, eighteen of them were issued CERs (41\%). The distribution of the projects according to the different sectors/categories is shown in Figure 1.

All projects related to the capture and flaring of methane from landfills as well as waste to energy projects were considered in the Waste sector (W). Projects linked to the mitigation of methane from industrial wastewater (through the recovery of biogas and flaring) or projects of methane avoidance were also considered in the same sector. Projects linked to the use of biomass residue for energy use (thermal or electricity) were considered as fossil fuel (FF) substitution and were in the Energy sector (E). Results showed that $91 \%$ of the projects were developed in E, W and Manufacture Industry (M) sectors.

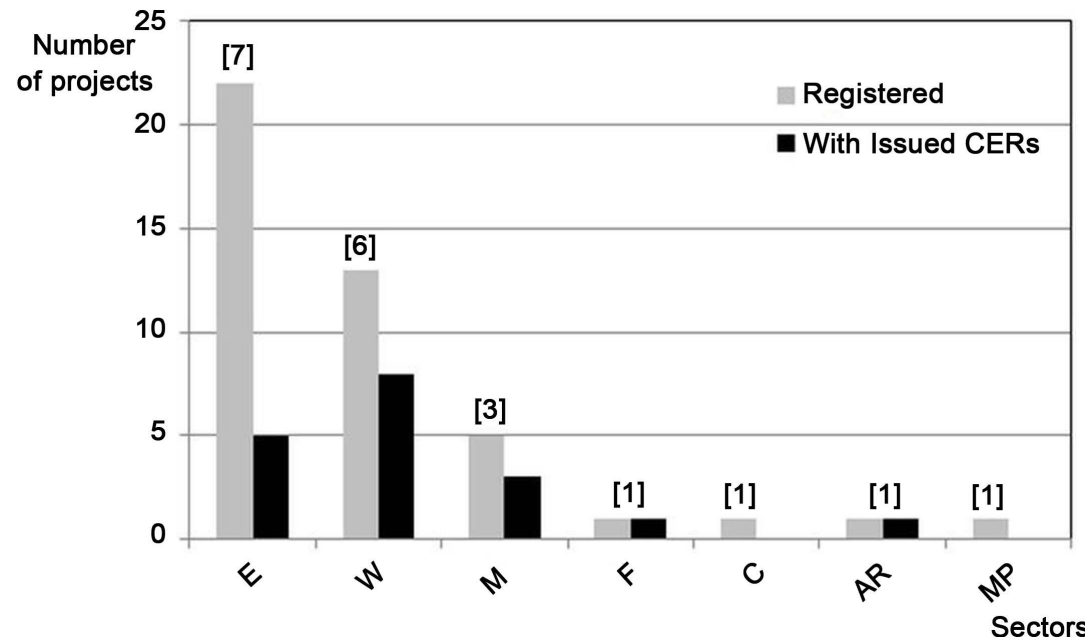

Figure 1. Type and number of registered projects with and without certifications of the emission reductions. The number of methodologies applied by sector is indicated between brackets. 
In the E sector twenty two projects were developed: nine wind energy projects, five fossil fuels substitution, two solar photovoltaic, two conversions from open to combined cycle, three cogeneration projects, and one hydroelectric. Wind energy projects consisted in the construction of wind power farms for supply electricity to the national grid. Wind farm Antonio Moran was a cooperative's first full-scale wind project of 10.56 MW capacity started in 2008 that accomplished the initial proposed energy production in shorter time than the initial estimate based on the fact that machines (European manufacturers) were developed for lower intensity winds than those in Patagonia; today the wind farm is out of service due to obsolescence of equipment and lack of maintenance. The rest of the wind projects were also installed throughout Patagonia and are currently operative with capacities varying between 6.3 to $50 \mathrm{MW}$, one of which was an umbrella project of 77.4 MW located at contiguous sites in the southeast of Argentina. The FF substitution projects were mainly developed in the food industry, four of which implemented anaerobic digestion in covered lagoon to capture methane for on-site thermal energy use. There were only one biomass project that employed direct combustion of peanut hull and sunflower husk to generate $10.95 \mathrm{MW}_{\mathrm{e}}$ of electric power for both on-site consumption and export to the national grid. Only one of the two solar $\mathrm{PV}$ projects are operative today. With an initial phase of $5 \mathrm{MW}$ (from a total of 20 $\mathrm{MW})$ is generating electricity to the national grid. One of the two projects of conversion from open to combined cycle succeeded in achieving additional $38 \mathrm{MW}$ of electric power; technology included the incorporation of two heat recovery steam generators (HRSGs) that utilize the waste heat from the two gas turbines to raise steam used for electricity generation. Technical failures and damage of the turbine of the second project prevented that it remains under operation. Co-generation projects included the use of conventional technology of water boiler and steam turbine coupled to electric generator for the production of steam for industrial consumption and electricity to be exported to the grid; the biomass used include bagasse, wood, sawmill and forest residues. The unique CDM hydroelectric project consists in a grid connected hydropower plant with an accumulation reservoir in San Juan's Province in Argentina, with a total installed capacity of $125 \mathrm{MW}$ that generates $239 \mathrm{GWh}$ per annum through two 62.5 MW turbines.

In Waste Handling and Disposal category there were developed six projects of extraction, collection, and flaring of landfill gas (LFG), five projects of waste to energy (electricity generation from LFG), one project of biogas recovery from wastewater treatment without energy use developed in a fruit processing plant and one project of methane avoidance in a poultry slaughterhouse wastewater system. In general, LFG projects were planned in two steps: a first one to achieve fully operational steady state of LFG capture system and a second one to advance in the electricity generation, for on-site consumption and the remainder to be exported to the national grid. Currently, only two projects related to the biggest landfills of Buenos Aires Metropolitan Area achieved these goals with installed capacities of 7.1 and 11.8 MW; the rest is flaring the LFG without energy use. 
From the five projects registered in $\mathrm{M}$ category, two correspond to energy efficiency and three to FF substitution. There were developed in the two highest cement companies of Argentina and in the energy industry. One innovative component in this sector is the reduction of energy consumption during the production of hydraulic lime (cement industry) by blending alternative material and additives after a stage of calcining, allowing an increase in volume and reducing the energetic consumption per unit of final product. The use of peanut shells (in cement kilns) and recovered flare waste gases that are normally burned in power station plants allowed $\mathrm{CO}_{2}$ mitigation through partial replacement of natural gas and fuel oil in manufacture sector.

Only one project was registered in each one of the following categories: Fugitive emissions (F) Afforestation/Reforestation (AR), Chemical Industries (C), and Metal production (MP). None project was registered in Agriculture sector. In F sector, the goal of the unique project is the reduction of $\mathrm{HFC}_{23}$ emissions by the capture, storage and thermal oxidation of $\mathrm{HFC}_{23}$ system by applying thermal oxidation technology in a CFCs- and $-\mathrm{HCFC}_{22}$ production plant located at San Luis province. The unique AR project focuses in the reforestation of grazing lands by using native and exotic species through direct planting with environmental-friendly techniques on grassland, generating carbon sequestration and high value forestry products in Santo Domingo, at northeast of Argentina. The chemical industry developed a project of $\mathrm{CO}_{2}$ removal and liquefaction from the intermediate gas in a hydrogen production facility located in Campana, Buenos Aires. The new activity includes the incorporation of a liquefaction unit and the use of MDEA (methyl diethanolamine) for gas washing on a conventional technology based on a steam methane reformer and a PSA (pressure swing adsorption) unit. In MP category, the only mitigation project focuses in the reduction of PFC emissions from the anode effect through the installation of a new algorithm in the Automatic Control System at the main aluminum smelter of Argentina located in Puerto Madryn in the Atlantic Coast.

Figure 2 describes the implemented projects by sector/category; percentages were calculated from the total number of projects in all categories/sectors.

Moreover the high potential mitigation estimated in $\mathrm{F}\left(11.5 \mathrm{MtCO}_{2} \mathrm{e}\right)$ and $\mathrm{W}(25.2$ $\mathrm{MtCO}_{2} \mathrm{e}$ ) sectors (due to the higher values of the global warming potentials GWP of methane and $\left.\mathrm{HFC}_{23}\right)$, the largest potential of emission reductions expected to be achieved in the production of electricity through renewable energies such as wind, solar photovoltaic and hydroelectricity, FF substitution for energy production, conversion from open to combined cycle, and cogeneration with biomass. In M sector two of the three registered projects that issued CERs focused on energy efficiency in cement production. Except by the absence of projects in the Agriculture sector and the number of implemented CDM activities, a first look at the sectors where mitigation activities were achieved resulted similar to Brazilian CDM experience [11].

With respect to the type of GHG mitigated, $28 \%$ correspond to $\mathrm{CO}_{2}$ (mainly by the substitution of $\mathrm{FF}$ ) while the rest are non- $\mathrm{CO}_{2}$ gases in a balanced distribution between methane $(52.7 \%$ from the capture in landfills and from anaerobic digestion of organic 


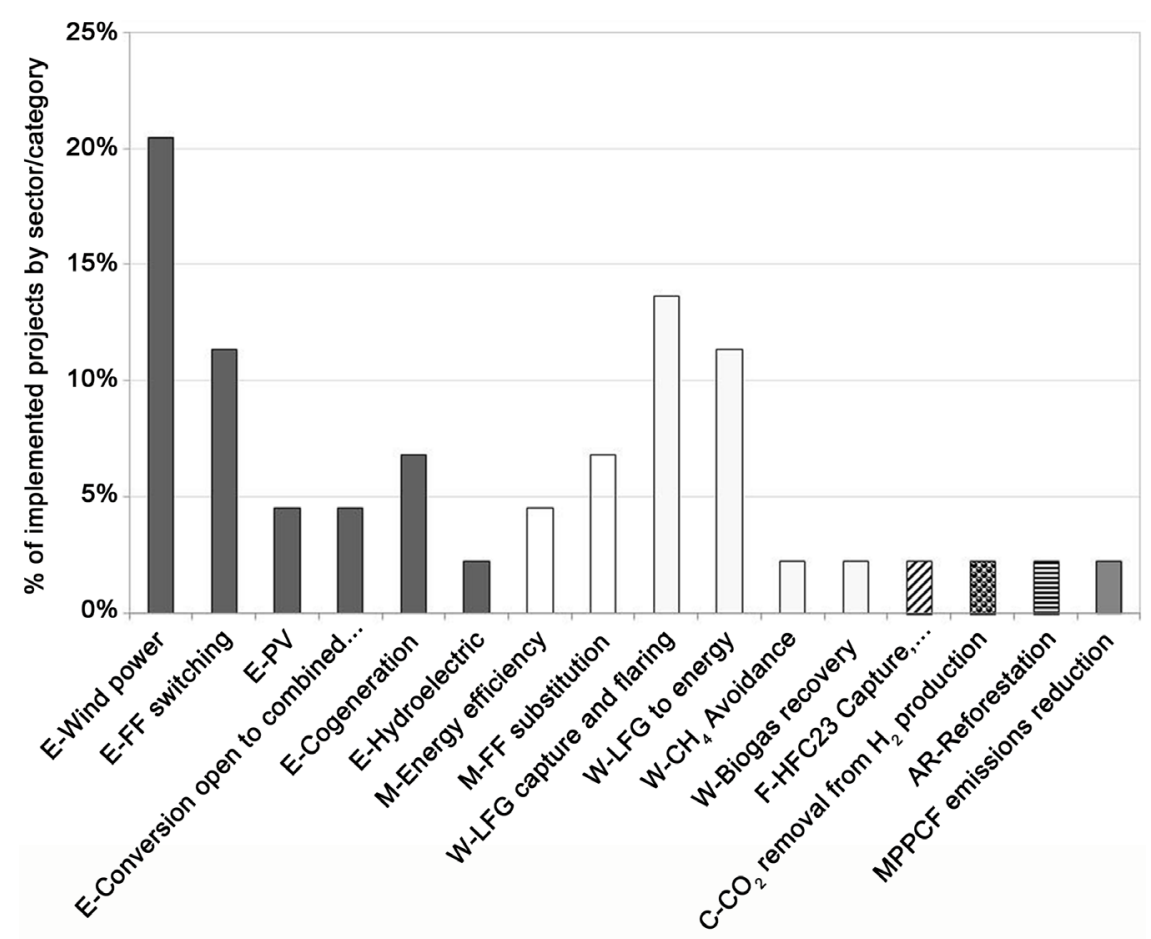

Figure 2. Percentage of implemented CDM projects in the different sectors/subsectors.

waste in the Waste sector) and the reduction of PCF (47.3\%, in aluminum production and the conversion of $\mathrm{HCF}_{23}$ ) as shown in Figure 3.

Regarding the scale of the projects, $68.2 \%$ correspond to full scale in a wide range of mitigation activities between $18.7 \mathrm{kt} \mathrm{CO}_{2} / \mathrm{yr}$ (Olavarría Landfill Gas Recovery and flaring) and $1434.1 \mathrm{kt} \mathrm{CO}_{2} / \mathrm{yr}$ (FIASA: $H_{F C}$ Capture, storage and decomposition). This wide range could be explained through the change in the SSC threshold occurred for Type III projects that was established at $15 \mathrm{ktCO}_{2} \mathrm{e} /$ year before January 2007 (as per 17/CP.7) and after this date (as per 1/CMP.2) changed to $60 \mathrm{kt} \mathrm{CO}_{2} / \mathrm{yr}$ ).

Figure 4 shows the different methodologies applied for the 44 registered projects. From the total of eighteen methodologies used, $22 \%$ corresponds to methodologies for the estimation of emission reductions for grid connected renewable electricity generation in renewable energy projects (ACM0002 and ACM001; AMS.ID and AMS.IIIH). Four small scale projects applied AMS.IIIH methodology for methane recovery in wastewater treatment coupled with AMS.ID for electricity production or AMS.IC for thermal energy. Energy and Waste sectors applied higher quantity of methodologies, seven and six respectively (Figure 1 between brackets). The consolidated baseline methodology for grid connected electricity generation from renewable sources ACM0002 was the most applied in the E sector followed by methodologies for small scale projects and the consolidated baseline and monitoring methodology for LFG project activities in the W sector ACM0001 (Figure 4). From all the applied methodologies $61.1 \%$ corresponds to full scale projects from which approximately and half of them (45.5\%) applied consolidated methodologies. 


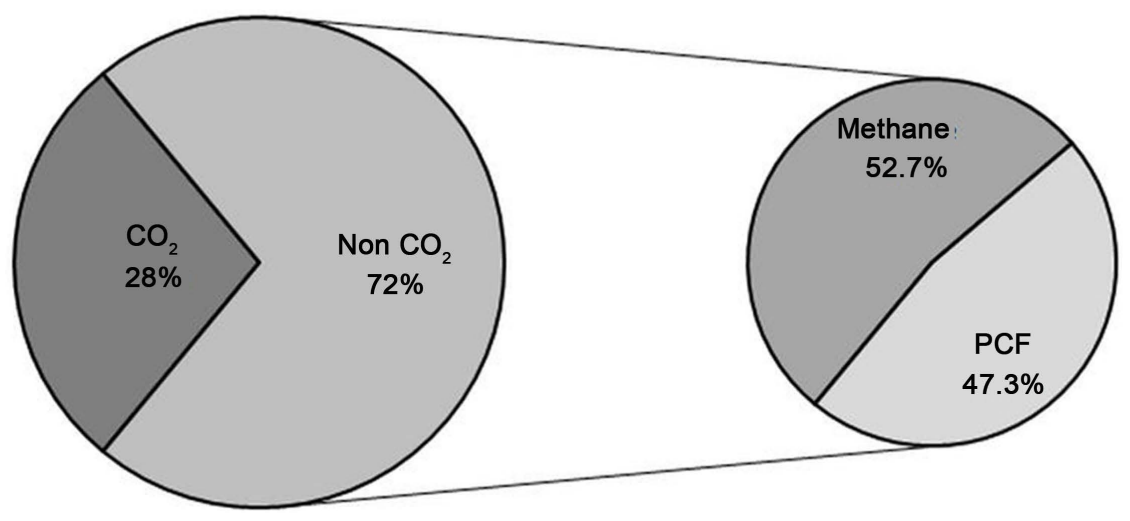

Figure 3. Types of GHG mitigated.

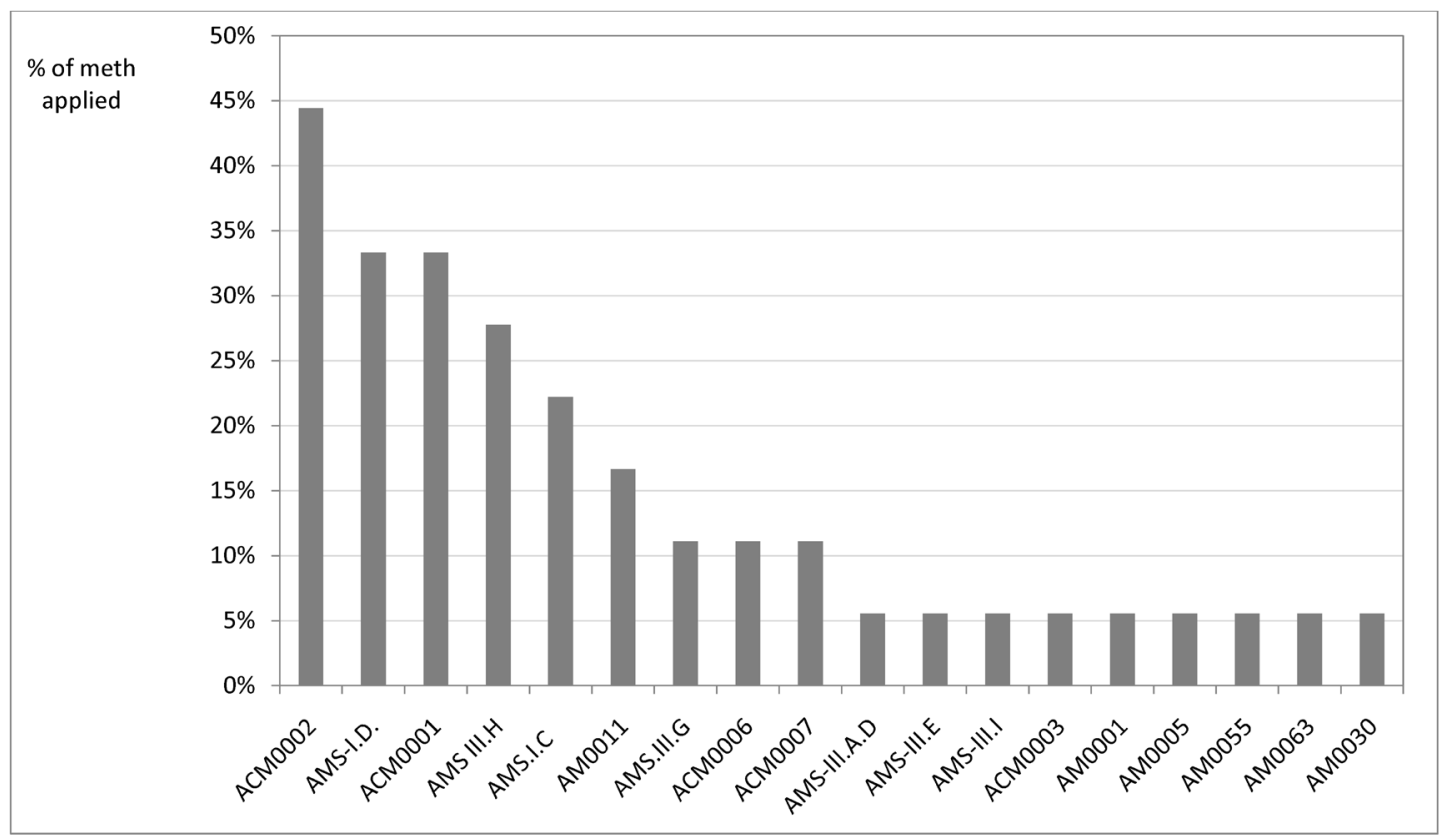

Figure 4. Methodologies applied in the registered CDM projects in Argentina.

Regarding the issuance of CERs, eighteen projects have attained certified emission reductions from 2006 to 2012. These emission reductions represent $33.4 \%$ of the potential emission reductions expected from all the projects until the end of 2012. Project performance for each sector calculated as the ratio between the actual CERs issued and the expected CERs (until 2012) was 11.9\% for E, 10.7\% for M, 28.6\% for W, 63.3\% for F and, 27.8\% for AR. C and MP sectors did not achieve certifications of emissions reduction during the period evaluated. Figure 5 details the expected (until 2012) and achieved CERs for each one of the operative projects. In terms of the amount of GHG mitigated, the capture, storage and decomposition of $\mathrm{HCF}_{23}$ and the methane captured from landfills became the higher sources of GHG mitigation. Non- $\mathrm{CO}_{2}$ projects mitigated almost $14.5 \mathrm{MtCO}_{2} \mathrm{e}$ while activities developed in the $\mathrm{E}$ and $\mathrm{M}$ sectors contributed with the mitigation of $1.2 \mathrm{MtCO}_{2}$ e during the evaluated period. 


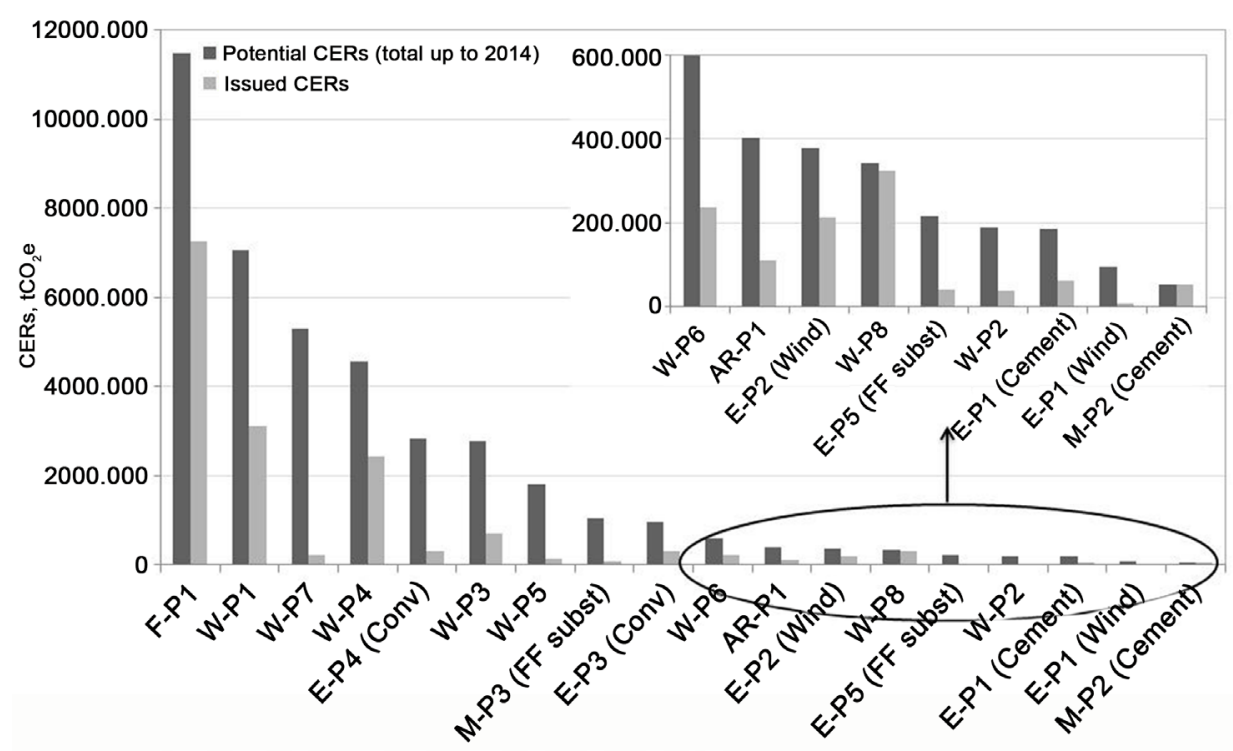

Figure 5. Expected (until 2014) and actual GHG mitigation by sector.

Within each sector, the percentage of projects that issued CERs was $23 \%, 62 \%$ and $60 \%$ for E, W and M sectors respectively and 100\% for both, F and AR sectors that implemented each one only one project, both of which delivered CERs.

In the E sector (renewable - non-renewable sources), from twenty two registered projects only five received CERs: two wind energy projects for electricity generation, two conversion from open to combined cycle, and one biomass combustion for electricity generation achieving FF substitution. The average performance of projects that issued CERs was $26 \%$, varying between $9.2 \%$ to $56.0 \%$ (both extremes from wind energy projects).

Five GHG mitigation projects were developed and implemented in the $\mathrm{M}$ sector: three of FF substitution (one in cement industry and two in oil refineries), and two of energy efficiency (in cement industry). The mitigation projects in the cement industry belong to small scale while those from oil refineries (energy industry) correspond to full scale. From the three CDM projects that issued CERs in the sector, the performance achieved was $49 \%$, varying between $8.5 \%$ (a FF substitution project in oil refinery) and $103 \%$ (a FF substitution project in a cement industry).

In the $\mathrm{W}$ sector, seven from the eight of the registered projects that issued CERs mitigated methane through the capture and flaring of LFG, two of which also mitigated $\mathrm{CO}_{2}$ through the electricity generation supplied to the national grid. Only one project issued CERs through the avoidance of methane. While eight out of the thirteen registered projects in the Waste sector achieved certifications, considering the seven LFG projects, the performance in terms of the ratio between expected and actual LFG collection varies from $4.3 \%$ to $53.4 \%$. The average for the sector (28\%) agreed with several studies carried out by different authors. A document from UNEP [12] pointed out that from 92 LFG projects in the CDM pipeline only $45 \%$ have successfully issued CERs). It has been reported that waste projects performed worst in terms of CER issuance, with 
only $31 \%$ of issued CERs. Authors pointed out that overestimations in the waste growth or in the landfill gas generation models, problems linked to management and operation of MSW disposal sites, and monitoring difficulties are the responsible factors of these results [13]. Along the same line, it has also pointed out that many LFG projects have faced real problems to deliver CERs. On average, LFG projects have only certified $31 \%$ of the expected CERs, highlighting that many factors influence performance being the regulatory framework and EB decisions only some of these [14]. The authors explained that in 2008, two requests for CER issuance from LFG flaring/energy projects were rejected and another two requests were withdrawn as the EB doubted that the realized discrete measurement of methane fraction of the LFG were in line with the methodology. This meant that a quarter of all issuance requests for LFG projects in 2008 were not successful due to problems in the measurement of the methane fraction.

The best performances from individual projects were achieved in $\mathrm{M}$ sector with the mitigation of $\mathrm{CO}_{2}$ in cement production (103\% of the expected CERs) followed by the avoidance of methane in the $\mathrm{W}$ sector (95\%) and the capture, storage and decomposition of $\mathrm{HFC}_{23}(63 \%)$.

\subsection{Analysis of CDM Contribution to Technology Transfer}

Four main conditions to establish technology transfer have been proposed, that were: 1) foreign origin, 2) novelty, 3) capacity building and 4) improvement of performance in terms of GHG mitigation [15]. While others applied more stringent criteria and described three types of technology transfer [16]:

Type I: a host country develops a specific technology for a CDM project with the collaboration of a foreign entity.

Type II: a technology import accompanied by a host country contribution of effort to improve or adapt the imported technology.

Type III: an import of technology or equipment accompanied by training to the local entity to operate and perform maintenance of imported technology.

Based on these two approaches, technology transfer in twelve Argentinean CDM of LFG capture projects were analyzed by using the four conditions mentioned above and the capacity building criteria [17].

It has been highlighted that equipment imports alone are not considered to be a technology transfer, unless such imports are accompanied by the building of technological capability such as training by foreign entities on operation and maintenance of the imported technology [18]. As an example, under these criteria, authors pointed out that CDM has produced a negligible number of projects that promote technology transfer in India. The importance of developing cleaner technologies that reduce production costs instead of CDM projects that solely promote end-of-pipe practices has been emphasized [4].

In the present study, technology transfer through CDM was analyzed considering: 1) technology origin (national/foreign), 2) novelty (new in the region/new technology/ new CDM methodology/first of its kind), 3) quality of the technology transfer (accord- 
ing to types I, II or III from [16]) and 4) performance in terms of verified CERs versus expected CERs.

Based on these criteria, the contribution of CDM to technology transfer in Argentina was little considering that from the total of 44 registered projects, $45 \%$ qualified as type III where technological learning and capacity building were only limited at the level of operation and maintenance of a foreign technology. Only one project qualified as type I for which the host country entity developed a technology in collaboration with a foreign entity (Figure 6).

According to several authors [19] [20], the definition of sustainable waste management is applied to integrated waste management in order to enhance and apply preventive waste management strategies that reduce, and preferably eliminate the waste problem. Most of CDM projects in the $\mathrm{W}$ sector were focused in the capture of methane from landfills for flaring and for electricity production, in the methane capture in wastewater for thermal/electric energy, and only one project in the avoidance of methane. At the level of Municipal Solid Waste (MSW) management, CDM projects did not contribute to promote activities to prevent waste generation, recycling practices or the introduction of cleaner technologies to improve leachate management in landfills. In fact, the certifications achieved represented a measure of the methane capture rather than the improvement of the waste management systems considering that landfill is at the bottom of most hierarchies of waste management; something that should be reviewed in future carbon market mechanisms.

Regarding the consulting services for the development of CDM projects, the analysis of the forty four registered projects indicated that only ten have been developed with local human resources (23\%); the rest were elaborated by foreign companies such as EcoSecurities (Brazil, United Kingdom), Van der Wiel Stortgas BV (The Netherlands), Asja Ambiente Italia SpA, CAF, PricewaterhouseCoopers, MGM International, Isolux Corsán Energías Renovables S. A. (Brazil), LA Global Carbon Trading Company Ltd, Conestoga-Rovers \& Associates Ltd. (Canada), AHL Carbono, Poch Ambiental S.A. (Chile), HYCHICO S.A., 33 Asset Management B.V. (The Netherlands), Mercuria

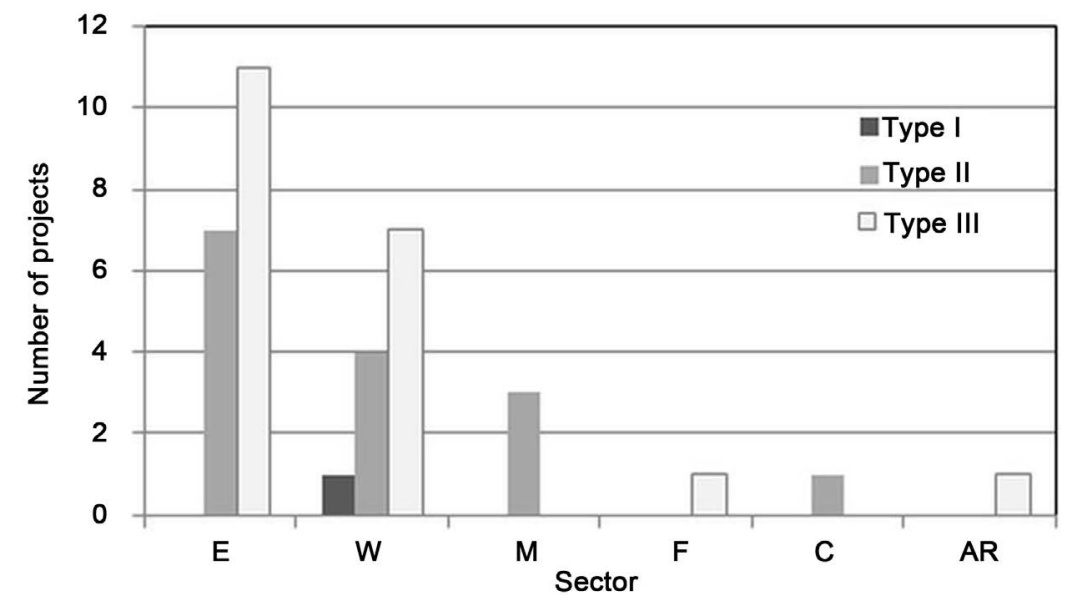

Figure 6. Type of technology transfer in CDM projects in Argentina. 
Energy Trading S.A. (Switzerland), Energy for Sustainable Development Ltd (UK), Pacific Consultants International PCI and Japan Carbon Finance Ltd.

\subsection{Description of the Policy Framework for the Development of Renewable Energy in Argentina}

Regional characteristics, technical and institutional capacities, regulatory frameworks, and cultural particularities in developing countries prevent the transfer of technologies from developed countries and the private sector. This could be alleviated, to certain extent, by the creation of enabling environments that can mitigate the barriers to invest, develop and implement climate friendly projects [10]. These barriers were analyzed during the Technology Needs Assessment (TNA) carried out in Argentina in 2012 [21]. The TNA report revealed that in the E sector, the main barriers for the development of renewable energy and the implementation of prioritized technologies are the regulatory framework of the electricity market and the distorted prices of electricity and natural gas due to the heavy subsidies applied. In the $\mathrm{W}$ sector, where technologies for electricity production were prioritized, a hardly controlled energy sector with monopolies and restrictions for private and independent electricity generation were identified as the main barrier to advance in the production of electricity based on renewable resources of the sector. Back in 2007, the national government implemented the GENREN Program to fulfill the National Law 26.190 that establishes a goal of $8 \%$ of the total electricity consumption to be supplied by renewable energy resources. This law was aim at diversifying the energy mix, reducing fossil fuels consumption, creating employment and promoting investments in the country. The first phase of the program (GENREN I) started in 2009 with a public bidding process that approved the provision of $895 \mathrm{MW}$ from renewable energy. This power would be provided from wind energy (electricity, $754 \mathrm{MW}$ ), bio-fuels (thermal, $110 \mathrm{MW}$ ), mini-hydro (11 MW) and photovoltaic solar (20 MW). Neither tidal, biomass, LFG or biogas projects were proposed in this initial phase. In 2010, the second phase of the program (GENREN II) was authorized by the Government in a second bidding process to provide a total of $1.208 \mathrm{MW}$. Several projects were awarded of which $85 \%$ corresponded to the provision of electricity from wind energy and the rest from solar, biofuels, biomass and small hydro. In both phases of GENREN, bidders fixed the energy price in US dollars and the Government guaranteed the purchase of energy for 15 years; four years later of being awarded only $24 \%$ of the projects were finished or are under construction. Companies mentioned the lack of funding due to uncertainty in the continuation of the public policy and the incapability of the administrator of the electricity market CAMMESA to guarantee the purchase of energy.

In this context, the potential impact of the CDM was investigated in order to assess whether this mechanism could be a driving force to the promotion of cleaner technologies under the current Argentina's framework on renewable energies. The objective of this analysis was to determine the fraction of the incremental costs of a renewable energy project under the GENREN that could be covered by the CDM. Table 1 
Table 1. Summary of data used to calculate the fraction that CDM could cover for the generation of electricity by using renewable energy.

\begin{tabular}{|c|c|c|c|c|c|c|c|}
\hline \multirow{2}{*}{$\begin{array}{c}\text { Renewable } \\
\text { Energy }\end{array}$} & \multicolumn{2}{|c|}{ GENREN Program } & \multirow{2}{*}{$\begin{array}{c}\text { Capacity } \\
\text { factor } \\
\%\end{array}$} & \multirow{2}{*}{$\begin{array}{c}\text { Investment } \\
\text { Costs }^{\mathrm{a}} \\
\mathrm{U} \$ \mathrm{~S} / \mathrm{MW}\end{array}$} & \multirow{2}{*}{$\begin{array}{c}\mathrm{O} \& \mathrm{M} \\
\text { Costs } \\
\mathrm{U} \$ \mathrm{~S}\end{array}$} & \multirow{2}{*}{$\begin{array}{c}\text { CERs } \\
\text { generated } \\
\mathrm{tCO}_{2} \mathrm{e}^{\mathrm{f}}\end{array}$} & \multirow{2}{*}{$\begin{array}{c}\text { Energy } \\
\text { generated } \\
\mathrm{MWh}^{\mathrm{g}}\end{array}$} \\
\hline & $\begin{array}{c}\text { Power } \\
\text { MW }\end{array}$ & $\begin{array}{c}\text { Price } \\
\text { U\$S/MWh }\end{array}$ & & & & & \\
\hline Wind & 754 & 126.9 & $31.0^{\mathrm{b}}$ & 1.750 .000 & 35.832 .342 & 980.782 & 2.047 .562 \\
\hline Mini-Hydro & 10.6 & 162.4 & $45.0^{c}$ & 2.000 .000 & 530.000 & 20.015 & 41.785 \\
\hline PV Solar & 20 & 571.6 & $35.0^{\mathrm{d}}$ & 4.650 .000 & 910.000 & 29.372 & 61.320 \\
\hline Biofuels & 110.4 & 287.6 & $61.5^{\mathrm{e}}$ & 1.950 .000 & 7.507 .200 & 138.973 & 725.328 \\
\hline
\end{tabular}

${ }^{\mathrm{a}}$ Investment and O\&M costs were considered from IPCC 2011 [25] (Table AIII.1, p 210) assuming on-land for Wind, PV

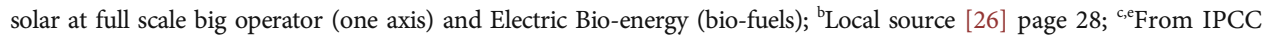
2011 [25], page 210, medium value of the proposed ranges; ${ }^{\mathrm{d}}$ Local source [27] page 14; ${ }^{\mathrm{f}}$ Obtained from the value of energy generated (MWh) and the emission factor of the public grid of electricity generation for the year 2012, official value annually updated by the Secretary of Energy http://energia3.mecon.gov.ar/contenidos/verpagina.php?idpagina=2311. For year 2012 the EF was $0.479 \mathrm{tCO}_{2} \mathrm{e} / \mathrm{MWh}$. For biofuels, the assumption was that they reduce only $30 \%$ of grid emission factor; ${ }^{\mathrm{g} C a l c u l a t e d ~ f r o m ~ P o w e r ~}(\mathrm{MW}) \times$ Capacity Factor $\times 8760$ (h/year).

summarizes the input data used for the calculation of this fraction for the generation of electricity through wind, mini-hydro, solar-PV and biofuels.

In order to calculate the cash flow for each project, a lifetime of 15 years and an annual discount rate of $7 \%$ were assumed. The incremental income from the selling of energy was calculated from the amount of energy expected for each renewable energy (Table 1) by the difference between de price of the energy proposed under GENREN Program (Table 1) and the price of energy in the current spot market that is $30 \mathrm{U} \$ \mathrm{~S} /$ MWh (CAMMESA as administrator of spot market [22]).

The income by the selling of CERs were estimated based on a CER price of 12 $\mathrm{U} \$ \mathrm{~S} / \mathrm{tCO}_{2} \mathrm{e}$ considering the top price before its downward trend [23].

Table 2 detailed the results of the cash flows applied and the fraction of the CDM contribution to the incremental costs from the implementation of each one of the renewable energy proposed in the GENREN Program (CDM validation, registration and transaction costs were not account in this preliminary analysis).

The fraction of the incremental costs covered by CERs resulted less than $6 \%$ for any of the renewable energies included in GENREN I.

A sensitivity analysis on the influence of both, the price of the energy in the baseline scenario and the price of CER was carried out in order to know the best combination that contribute to widespread the electricity production based on renewable energy. Figure 7 showed that by increasing the price of the energy by $400 \%$ with a price of CERs of $24 \mathrm{U} \$ \mathrm{~S} / \mathrm{tCO}_{2} \mathrm{e}$, the fraction of the incremental cost that CDM would cover is less than $15 \%$. At the current energy price (U\$S 30/MWh) the CER should have a value of $360 \mathrm{U} \$ \mathrm{~S} / \mathrm{tCO}_{2} \mathrm{e}$. In the case that the energy price would have a value of U\$S 100/MWh, close to other countries in the region such as Chile and Brazil [24] a price of CER of $190 \mathrm{U} \$ \mathrm{~S} / \mathrm{tCO}_{2} \mathrm{e}$ would cover the whole of the incremental costs. 


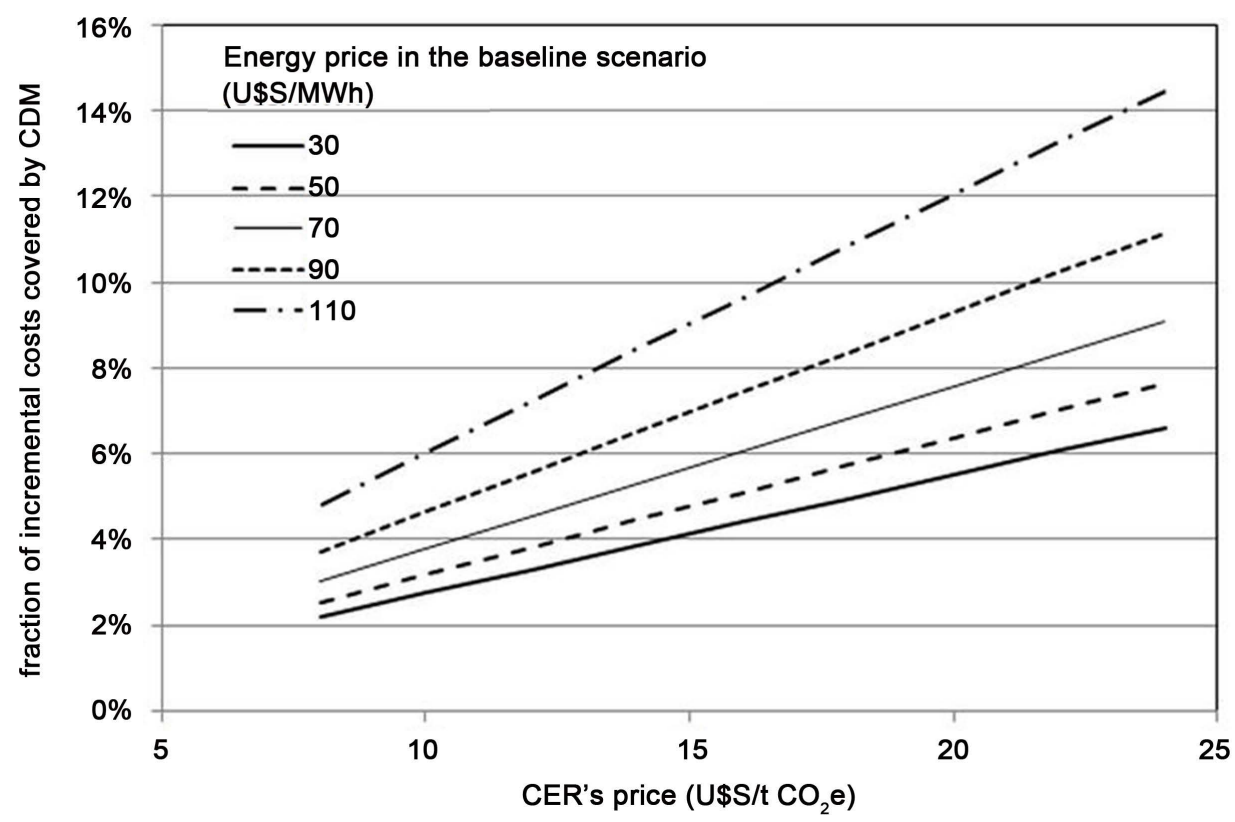

Figure 7. Sensitivity analysis of the impact of CDM on the implementation of renewable energy for electricity generation in Argentina.

Table 2. Results of the cash flow and incremental costs of renewable energies during the lifetime of the program

\begin{tabular}{ccccccc}
\hline $\begin{array}{c}\text { Renewable } \\
\text { energy }\end{array}$ & $\begin{array}{c}\text { Total costs } \\
\text { U\$S }\end{array}$ & $\begin{array}{c}\text { NPV } \\
\text { U\$S }\end{array}$ & $\begin{array}{c}\text { IRR } \\
\%\end{array}$ & $\begin{array}{c}\text { Incremental } \\
\text { costs U\$S }\end{array}$ & $\begin{array}{c}\text { CERs/incremental } \\
\text { costs } \%\end{array}$ & $\begin{array}{c}\text { CERs/LCOE } \\
\%\end{array}$ \\
\hline Wind & $2,366,560,925$ & $720,703,035$ & 7.33 & $1,807,090,257$ & 5.93 & 18 \\
Mini-Hydro & $61,805,544$ & $35,778,349$ & 20.42 & $50,388,263$ & 4.34 & 23.2 \\
PV Solar & $319,237,049$ & $217,948,847$ & 27.44 & $302,482,131$ & 1.06 & 8.7 \\
Biofuels & $1,899,950,324$ & $1,451,167,173$ & 44.52 & $1,701,763,573$ & 0.89 & 9.3 \\
\hline
\end{tabular}

${ }^{\mathrm{a} C a l c u l a t e d ~ f r o m ~ t h e ~ l e v e l i z e d ~ c o s t ~ o f ~ e n e r g y ~(U \$ S / M W h) . ~}$

When the analysis is carried out independently of the offered price under the GENREN Program by using the ratio between the income by CERs and the LCOE the fractions remains very low as can be observed from figures in the last column of Table 2. This ratio was calculated from the levelized cost of energy (U\$S/MWh) based on the annuity (U\$S/year) divided by the annual energy produced (MWh/year) and the price that $\mathrm{CDM}$ pays by $\mathrm{kWh}$ of renewable energy produced (obtained from the emission factor of the grid times the price of CER).

The previous analysis did not include the costs involved in the CDM project cycle, and the fact that most DOEs do not have offices in Argentina.

\section{Conclusions}

From this assessment on the implementation of the CDM projects in Argentina, several conclusions can be attained in relation to the two main goals of the CDM: “... to assist 
Parties not included in Annex I in achieving sustainable development and in contributing to the ultimate objective of the Convention, and to assist Parties included in Annex I in achieving compliance with their quantified emission limitation and reduction commitments under Article 3" of the Kyoto Protocol.

Firstly, on the mitigation side, most of the projects implemented delivered less emission reductions than expected. The reason for this can be found in multiple aspects both domestic and external.

Among domestic aspects that undermined the performance of the projects are technical and institutional capabilities as well as the lack of a robust regulatory framework for many project activities, mainly those related to electricity generation. In some cases, the lack of financial capabilities to address initial investments and the need to import technologies added to the overall burden. Several external aspects that negatively influenced the projects' performance, real or apparent, were also found. Among these are the methodologies that overestimate the amount of emission reductions to be achieved by the projects. This initial overestimation led to wrong economic evaluation and analysis of the projects with negative consequences such as the discontinuation of project activities in the worst cases.

Other external aspects that influenced the performance of projects, although indirectly, were the conditions established in the contracts for the purchasing of CERs, including the CER price.

Finally, the complexity of the project cycle together with the verification and certification of emission reductions did not contribute to the performance of the projects.

Secondly, the contribution to sustainable development of CDM projects in Argentina was very little. Projects activities did not contribute substantially to the development or transfer of technologies in any of the sectors involved. In some cases the necessary hardware was imported but not the know-how. In other cases technologies were developed locally, as for the capture of landfill gas, but a domestic market for such equipment has yet to be developed.

Due to the domestic and external factors described, the CDM project activities did not expand across the sectors and, as a consequence, none of these sectors have changed its common practices.

In relation to the financial contribution of the CDM in Argentina, the figures shown in Table 1 and Table 2 are eloquent. It can be concluded from the analysis that, in some cases such as in the renewable energy projects where the incremental costs are higher than the return perceived by the selling of CERs, Argentina ended up financially supporting the GHG mitigation in the CERs purchasing countries.

The lessons learned from the implementation and performance of CDM project activities in Argentina should contribute to the design and implementation of the new carbon market under the global climate change agreement expected to be agreed upon during COP 21 in Paris, 2015, if parties to the UNFCCC decided to include such carbon market as part of the agreement.

Several aspects should be considered for a future carbon market. In the first place it 
should be considered whether a GHG emissions offset mechanism is longer appropriate vis-a-vis the need for deep emissions reductions to be achieved globally, including in developing countries. A non-offset mechanism where countries involved can buy and sell GHG emission reductions could avoid the discussion about whether a project activity contributes to sustainable development or the necessary discussion about whether the financial flows under the current CDM could be considered part of the climate financial support as described in the UNFCCC.

\section{References}

[1] Sutter, C. and Parreño, J. (2007) Does the Current Clean Development Mechanism (CDM) Deliver Its Sustainable Development Claim? An Analysis of Officially Registered CDM Projects. Climatic Change, 84, 75-90. http://dx.doi.org/10.1007/s10584-007-9269-9

[2] Ellis, J., Winkler, H. and Corfee-Morlot, J. (2007) CDM: Taking Stock and Looking Forward. Energy Policy, 35, 15-28. http://dx.doi.org/10.1016/j.enpol.2005.09.018

[3] Umamaheswaran, K. and Michaelowa, A. (2006) Additionality and Sustainable Development Issues Regarding CDM Projects in Energy Efficiency Sector. Discussion Paper 346, HWWA Hamburg. http://www.hwwa.de

[4] Pearson, B. (2007) Market Failure: Why the Clean Development Mechanism Won't Promote Clean Development? Journal of Cleaner Production, 15, 247-252. http://dx.doi.org/10.1016/j.jclepro.2005.08.018

[5] Jotzo, F. and Michaelowa, A. (2002) Estimating the CDM Market under the Marrakesh Accords. Climate Policy, 2-3, 179-196. http://dx.doi.org/10.3763/cpol.2002.0219

[6] Song, J. (2010) The Road to the Successful Clean Development Mechanism: Lessons from the Past. Ph.D. Thesis in Engineering Systems, Massachussetts Institute of Technology.

[7] Zhu, J. (2012) The Correlated Factors of the Uneven Performances of the CDM Host Countries. Environmental Research Letters, 7, 01401. http://dx.doi.org/10.1088/1748-9326/7/1/014015

[8] Seres, S., Haites, E. and Murphy, K. (2009) Analysis of Technology Transfer in CDM Projects: An Update. Energy Policy, 37, 4919-4926.

http://dx.doi.org/10.1016/j.enpol.2009.06.052

[9] Dechezleprête, A., Glachant, M. and Ménière, Y. (2008) The Clean Development Mechanism and the International Diffusion of Technologies: An Empirical Study. Energy Policy, 36, 1273-1283. http://dx.doi.org/10.1016/j.enpol.2007.12.009

[10] Blanco, G., de Coninck, H. and Würtenberger, L. (2012) The Technology Mechanism under the UNFCCC: Ways Forward. Report from UK Department for International Development (DFID) and the Netherlands Directorate-General for International Cooperation (DGIS). Policy Brief, 16 p. http://www.climatestrategies.org/research/ourreports/category/78/364.html

[11] Costa-Júnior, A., Pasini, K. and Andrade, C. (2013) Clean Development Mechanism in Brazil: An Instrument for Technology Transfer and the Promotion of Cleaner Technologies? Journal of Cleaner Production, 46, 67-73. http://dx.doi.org/10.1016/j.jclepro.2012.09.044

[12] UNEP DTU (2016) Centre of Energy, Climate and Sustainable Development http://www.cdmpipeline.org/cers.htm

[13] Castro, P. and Michaelowa, A. (2008) Empirical Analysis of Performance of CDM Projects. Climate Strategic Reports. Climate Strategies c/o Cambridge Centre for Energy Studies, 
A0.03 Judge Business School Trumpington Street, Cambridge University. www.climate-strategies.org

[14] Freestone, D. and Streck, C. (2009) Legal Aspects of Carbon Trading: Kyoto, Copenhagen, and beyond. Oxford Scholarship Online.

[15] Cools, S. (2007) Assessing Technology Transfer in the Clean Development Mechanism. $\mathrm{MScD}$, University of Oslo, Norway.

[16] Das, K. (2011) Technology Transfer under the Clean Development Mechanism: An Empirical Study of 1000 CDM Projects. Working Paper Series, The Governance of Clean Development, WP 014, University of East Anglia. www.clean-development.com www.uea.ac.uk/dev

[17] Barnes, Q. (2013) El boom de la basura: La transferencia de tecnología en los rellenos sanitarios argentinos provenientes del MDL. MScD. Thesis, Facultad Latinoamericana de Ciencias Sociales (FLACSO), Argentina.

[18] Phillips, J., Das, K. and Newell, P. (2013) Governance and Technology Transfer in the Clean Development Mechanism in India. Global Environmental Change, 23, 1594-1604. http://dx.doi.org/10.1016/j.gloenvcha.2013.09.012

[19] Tchobanoglous, G. and Kreith, F. (2002) Handbook of Solid Waste Management. 2nd Edition, McGraw Hill Handbooks. New York.

[20] United States Environmental Protection Agency (2002) Solid Waste Management: A Local Challenge with Global Impacts. Report EPA530-F-02-026d (5306W). Solid Waste and Emergency Response. www.epa.gov/globalwarming

[21] Santalla, E. and Córdoba, V. (2012) Technologies for the Energy Use of Municipal Solid Waste, Agricultural and Industrial Waste. Project of Technological Need Asssessment for the Mitigation and Adaptation to Climate Change in Argentina. Ministry of Science, Technology and Productive Innovation MINCyT-Risoe Centre.

http://www.tech-action.org/Participating-Countries/Phase-1-Latin-America-and-the-Carib bean/Argentina

[22] CAMMESA. Àdministrator Company of the Wholesale Electricity Market in Argentina. http://portalweb.cammesa.com/default.aspx

[23] Kossoy, A., Opperman, K., Platonova-Oquab, A. and Suphachalasai, S. (2014) State and Trends of Carbon Pricing. World Bank Group. Climate Change. Report 88284. Ecofys.

[24] Library of the National Congress of Chile (2012) Comparative of Electricity Prices between Chile, OCDE and LAC Countries.

http://www.bcn.cl/obtienearchivo?id=repositorio/10221/16020/1/Informe_Comision\%20Fi nal_v4.doc

[25] IPCC, Edenhofer, O., Pichs-Madruga, R. and Sokona, Y. (2011) Renewable Energy Sources and Climate Change Mitigation Special Report of the Intergovernmental Panel on Climate Change. Cambridge University Press.

[26] National Secretary of Energy Argentina (2004) Description, Development and Perspectives of Renewable Energies in Argentina and in the World. Technical Report. http://www.energia.gob.ar/contenidos/verpagina.php?idpagina=3881

[27] Brown, N. (2013) Why Renewable Energies Make Sense? How to Make Them Happen? Course of Master in Energy Management Universidad de Lanús. Comisión Nacional de Energía Atómica CADER. Argentine Chamber of Renewable Energies. Camara Argentina de Energías renovables. http://www.cader.org.ar/ 
Submit or recommend next manuscript to SCIRP and we will provide best service for you:

Accepting pre-submission inquiries through Email, Facebook, LinkedIn, Twitter, etc. A wide selection of journals (inclusive of 9 subjects, more than 200 journals)

Providing 24-hour high-quality service

User-friendly online submission system

Fair and swift peer-review system

Efficient typesetting and proofreading procedure

Display of the result of downloads and visits, as well as the number of cited articles

Maximum dissemination of your research work

Submit your manuscript at: http://papersubmission.scirp.org/

Or contact ajcc@scirp.org 